\title{
Exploring the Effects of the COVID-19 Pandemic on International Students and Universities in Canada
}

\author{
David Firang \\ Trent University, Peterborough, Ontario \\ Joseph Mensah \\ York University, Toronto, Ontario, Canada
}

\begin{abstract}
International students in Canada make an enormous contribution to the Canadian economy. As domestic students' enrollment has declined, international students' admissions have compensated for economic losses that Canadian universities incur from the decline of domestic students' enrollment. However, the COVID19 pandemic is impacting international students' admissions to Canadian universities. Drawing on various secondary data sources, this article argues that international students in Canada are vulnerable due to their temporary immigration status. They are excluded from most government relief programs aimed at supporting Canadians during this pandemic. Most international students experience psychological and financial difficulties amid the pandemic. The situation is triggering a further decline in international students' admission, creating economic implications for Canadian universities. By exploring the challenges facing international students and the strategies required to strengthen their resilience and universities' capacities, this article contributes to our understanding of the plights of international students and educational institutions amid the COVID-19 pandemic.
\end{abstract}

Keywords: Canada, Canadian universities, COVID-19, international students, pandemic 
Due to the opportunities international education offers to most study destinations of the Global North, including Canada, international student migration has increased tremendously over the last few decades. In Canada, the number of international students has tripled to over 600,000 in the last two decades (Canada Bureau for International Education [CBIE], n.d.). International students who choose Canada as their study destination bring new cultural ideas and economic prosperity to the country. The Immigration Refugee Center Canada (Immigration Refugees and Citizenship Canada [IRCC], 2019) reported in 2018 that international students in Canada contributed an estimated $\$ 21.6$ billion to Canada's gross domestic product (GDP), and supported almost 170,000 jobs for Canada's middle class. After completing their studies, international students who stay permanently in Canada continue to contribute to Canada's economic success in many diverse ways. Those who return to their country of origin become lifelong ambassadors to enhance Canada's international reputation (Global Affairs Canada [GAC] 2017; IRCC, 2019). The immense contributions international students make to the Canadian society and economy has motivated Canadian governments and universities to recruit and retain international students. At a time that Canadian universities are struggling to maintain adequate enrollment, the current global health crisis caused by the coronavirus (COVID-19) pandemic is even making it more challenging to recruit and retain international students in Canada. While the pandemic continues, international students become more vulnerable as they experience financial and psychosocial crises. At the same time, Canadian universities are economically impacted as declines in international student enrollment is plummeting international students' tuition revenue. The approach by which Canadian universities and governments respond to international students' plights during the COVID-19 pandemic will motivate international students to continue to select Canada as their study destination.

As King and Raghuram (2013) noted, research on international students is understudied among migration scholars. Even while the scant literature on international students offers broad perspectives on their migration intentions and outcomes (e.g., Choudaha, 2017; McGill, 2013; Varghese, 2008), studies on how global and national crises, such as a pandemic, impact international students are very limited. However, following the COVID-19 pandemic, scholars have begun to document international students' experiences during this time (e.g., Fakhar-eAlam et al., 2020; Ferdiansyah et al., 2020; Firang, 2020; Hagar, 2020; Lipura, 2021). While scholarly research on COVID-19 and international students is emerging elsewhere in the world, Canadian scholars have yet to explore the impact of the pandemic on international students in Canada, with the exception of Firang (2020) and Hagar (2020).

This article adds to the emerging literature on international students and COVID-19 by exploring the experiences of international students amid the COVID-19 pandemic as well as the economic consequences of the pandemic on Canadian universities. Specifically, this article aims achieving the following objectives: (a) examining the trend of international students in Canada; (b) exploring the difficulties and challenges international students experience during the pandemic;(c) understanding the economic impacts of the pandemic on 
Canadian universities, in general; and (d) suggesting appropriate strategies required to strengthen international students' resilience to deal with the pandemic and universities' capacities to address challenges facing international students. Given that conceptual and empirical research on COVID-19 and international students is limited at this stage, the objectives are achieved through secondary sources. In this article, international students in Canada are defined as foreign students who migrate to seek university education in Canada.

\section{THEORETICAL FRAMEWORK}

The bulk of the existing studies on international students' mobility have mostly examined neoclassical economic theory (e.g., Sassen, 1998), the push-pull model (e.g., Massey et al., 1994; Robinson, 2005), and neo-liberalism (e.g., Boyd, 2013; Menz, 2011) to understand the international student mobility process. Other studies have also focused on migration outcomes, mainly on how international students settle in their study destinations (Boyd, 2013; McGill, 2013). Conspicuously missing in the migration literature is how international students cope with crises, such as the current global health crisis, in their study destinations. Amid the current pandemic, the theoretical frameworks of a neoclassical economic perspective, the push-pull model, and neo-liberalism alone cannot adequately explain international students' mobility. The free flows of international students' financial, human, and cultural capital to study destinations, as explained by neo-classical and neo-liberal theoretical perspectives, are now partially distorted due to the pandemic. The distortions and uncertainties are reflected in the chaos of traveling restrictions, border closures, and schools' lockdowns, which, in turn, impact both imports and exports of students across the globe. Therefore, we need to search for a better way of addressing international students' mobility and retention in the era of this global health crisis. Psychological theoretical frameworks of crisis and resilience models are useful to understand how international students can adjust to and cope with the current pandemic crises.

\section{Psychological Models}

In an attempt to examine the psychological wellness and coping mechanisms of international students, existing and emerging studies have focused more on psychosocial models of social exclusion and overt racist and microaggression (Belkhodja, 2013; Zhang \& Zhou, 2010) to understand the challenges facing international students' experiences in Canada. Others have also examined international students' experiences of anxieties, distress, fears, and stressors during crisis and emergency situations at the expense of more positive factors conducive to the health and well-being of international students (e.g., Dorado Barbé et al., 2021; Ferdiansyah et al., 2020; Lipura, 2021; Pappa et al., 2020). Unlike these studies that utilize psychosocial perspectives of anxieties, depression, stressors, and social exclusion, this article examines psychological frameworks of crisis and resilience models to better understand how international 
students draw on their unique strengths to deal with difficult circumstances amid the current pandemic. Thus, rather than focusing on international students' stressors and worries, our theoretical framework of crisis and resilience models help to better contextualize how international students and Canadian universities can deal with, and cope with, the challenges the current pandemic presents.

According to the crisis theory, any situation for which a person or group of persons does not have adequate coping skills is deemed a crisis (James, 2008; Regehr, 2011). Crises may range from seemingly minor situations, such as not being prepared for class, to significant life changes, such as divorce, to extremely catastrophic situations, such as environmental disaster and health crises (James, 2008; Regehr, 2011). The central tenant of crisis framework is that a little help, rationally directed and purposefully focused on a strategic time is a more effective solution to support people going through crisis (Miller, 2011; Regehr, 2011). The crisis model allows us to assess peoples' coping capacity during emergency situations in assessing safety, identifying problems, addressing feelings, generating alternatives, developing an action plan, and conducting follow-ups (Miller, 2011). Thus, for international students who are currently experiencing emotional distress, financial difficulties, and social isolation during the current global pandemic, the crisis theoretical perspective provides a framework to develop appropriate intervention to assist international students in coping with the current impacts of the COVID-19 pandemic. However, crisis theory does not capture people's strengths and capacities to cope with the pandemic. While crisis theory may help with the tools to contain the current pandemic, it is the resiliency model that provides a framework to examine international students' capacities to develop appropriate coping skills to deal with the pandemic.

Resiliency, a strength-based model, can be utilized to manage crises like the current COVID-19 pandemic. Human resiliency, a term often used in psychology and social work, has emerged as an intervention strategy in the health and social sciences over the past decade. In psychology and social work, human resiliency focuses on the dynamic capacities for fostering healthy development and adaptation for individuals, groups, and communities during a crisis (Kaplan, 2005; Luthar, 2003). Resilience, a trait developed through life experience, influences how individuals respond to challenging situations (Mullaly, 2010). Resilience is conceptualized as the "ability of individuals and groups to adapt, absorb, overcome, deal with, adjust to, respond to, tolerate, withstand, cope with, mitigate, manage some form of undesirable social and environmental circumstances" (Akbar \& Preston, 2019, p. 4). Further, Akbar and Preston (2019) illustrated three distinct interpretations of resilience: (a) coping capacities - the ability of individuals and groups to cope with and overcome all kinds of hardships and adversities; (b) adaptive capabilities - the ability to learn from past experiences and adjust to future everyday challenges; and (c) transformative capacities - the ability to craft institutions that foster individual welfare and sustainable societal robustness toward future crises. While all these interpretations of resilience are relevant, the first two are more meaningful to international students' experience amid the current health crisis. For international students experiencing difficult circumstances in the COVID-19 pandemic, resilience suggests individual coping 
capacities (Akbar \& Preston, 2019) that allow these international students to successfully adapt to the adversity and challenges presented by the pandemic. Various personality traits (e.g., self-esteem, motivation, enthusiasm, and competence) and social resources (e.g., social support networks) create protective factors (Akbar \& Preston, 2019) to bolster international students' capacities to overcome the challenges COVID-19 presents.

Our review of these theoretical perspectives is not intended to denounce the utility of conventional migration frameworks of neo-classical, push-pull, and neo-liberalism for analyzing international student mobility. The three migration frameworks and the psychological models explain completely different elements of the international student experience. While the crisis and resilience models can only speak to the micro-level experiences of international students regardless of migration process, the migration frameworks deal with both micro- and macrolevel patterns and trends of student migration.

\section{METHOD}

At this stage, there is very little published scholarly material on international students and COVID-19, except gray literature in electronic and print media (e.g., Firang, 2020). A library search on the keywords and phrases like "international students" and "COVID-19," on major academic databases, including Google Scholar, Omni, Scopus, Web of Science, and Microsoft Academic, produced little discourse, writings, or literature with empirical studies or conceptual and theoretical articles on COVID-19 and international students. Thus, this article draws on various secondary sources, including academic papers, policy briefs, government surveys, reports, credible media sources, press notes and advisories, and current newspaper and online media reportage of the unfolding health crisis about COVID-19. Subsequently, we collected and analyzed secondary data from Canadian universities and Canadian government websites, international nonprofit Canada Bureau for International Education (CBIE), UNESCO, and the Ontario Ministry of Education and Advanced Training to profile international student enrollment through time to understand how the pandemic is impacting international students and universities in Canada. In interpreting the COVID-19 data in this article, we caution readers that it is an uncertain venture to write about the pandemic at this stage, as there are many unknowns about the virus. The dynamic circumstances surrounding the virus are still evolving in many countries, and so is its impact. How, where, and when the virus will end is still uncertain, and it is too early to predict its expected and actual impact. Nonetheless, some scientific observations about the virus continue to change daily. Hence, some of the ideas presented in this article may or may not remain valid.

\section{RESULTS AND DISCUSSION}

In line with our methodological framework, we analyze and discuss findings from secondary data sources with respect to international students in Canada and the COVID-19 pandemic to shed insights about the impacts of COVID-19 on 
international students particularly, and Canadian universities generally. We commence our analysis with the rising trend of international students in Canada and their contribution to the Canadian economy to set the context. This analysis brings to the fore the idea that global competition for foreign students has dramatically increased over the last two decades.

\section{The Rising Trend of International Students in Canada}

Table 1 illustrates the rising trend of international students and their contribution to the Canadian GDP. The table clearly shows that Canada's international student population has grown six-fold over the last two decades. In the last decade alone, there has been a sharp increase in Canada's international student population, with the number tripling to over 642,000 in 2019 (IRCC, 2020). Canada has moved into third place globally behind the United States and Australia as the most attractive study destination for international students (CBIE, n.d.; IRCC, 2020). The rising trends of international students in Canada also boosts international students' contribution to the Canadian GDP. As seen in Table 1, since 2011, steady growth in the number of international students in Canada correlates positively with international students' contribution to Canada's GDP. Exceptionally, the last three years have seen a drastic increase in the GDP contributions from international students in Canada. In 2019 alone, international students added roughly \$21 billion to Canada's GDP (IRCC, 2019).

Table 1: International Students in Canada and Their Contribution to the Canadian GDP

\begin{tabular}{llc}
\hline Year & $\begin{array}{l}\text { Number of international } \\
\text { students }\end{array}$ & $\begin{array}{l}\text { GDP contribution } \\
\text { (\$ billion CDN) }\end{array}$ \\
\hline 2000 & 125,000 & 4.2 \\
2001 & 148,000 & 4.3 \\
2002 & 176,000 & 4.4 \\
2003 & 182,000 & 4.5 \\
2004 & 184,000 & 4.6 \\
2005 & 188,000 & 4.8 \\
2006 & 191,000 & 5.1 \\
2007 & 193,000 & 5.3 \\
2008 & 197,000 & 4.7 \\
2009 & 202,000 & 4.8 \\
2010 & 225,000 & 4.2 \\
2011 & 267,000 & 6.8 \\
2012 & 281,000 & 7.2 \\
2013 & 304,000 & 8.4 \\
2014 & 327,000 & 9.3 \\
2015 & 350,000 & 10.5 \\
2016 & 410,000 & 12.8 \\
2017 & 495,000 & 17.5 \\
\hline
\end{tabular}




\begin{tabular}{lll}
\hline Year & $\begin{array}{l}\text { Number of international } \\
\text { students }\end{array}$ & $\begin{array}{l}\text { GDP contribution } \\
\text { (\$ billion CDN) }\end{array}$ \\
\hline 2018 & 581,000 & 20.7 \\
2019 & 642,000 & 21.6 \\
\hline
\end{tabular}

Note: The number of international students is rounded to the nearest thousand. Adapted from Building on Success: Canada's International Education Strategy (2019-2024), by Immigration, Refugees, and Citizenship Canada, 2019. Copyright 2019 by the Government of Canada.

In Canada, a widely held belief that immigration is the key to nation-building and to meeting the demands of labor market gaps has pushed federal authorities, particularly IRCC, the Ministry of Finance, and Education and Labour, to identify international students as a critical component of the national development plan (CBIE, n.d.). Fortunately for Canada, hostile economic and political environments (push factors) in most home countries of international students and favorable pull factors in Canada have lured international students to Canada for higher education in an unparalleled proportion. Difficulties in accessing stable quality education in their homelands and relatively higher education costs in traditional study destinations, such as in the United States, United Kingdom, and Australia, have compelled a growing number of international students to seek Canada as an alternative study destination. International students recognize Canada's affordable quality education and perceive Canada as an inclusive and tolerant society (CBIE, n.d.). It is no wonder that international students' migration to Canada has surged over the last 20 years (IRCC, 2020).

Migrating from more than 180,000 countries, international students who come to Canada are ethnically and culturally diverse (CBIE, n.d.; IRCC, 2019), enriching Canada's multiculturalism. CBIE (n.d.) reported that, in 2015, 33\% of international students pursuing studies in Canada came from East Asia (mostly China), while about a quarter originated from South Asia (mainly from India). Since 2015, the proportion of international students from South Asia has grown considerably from $16 \%$ to $27 \%$, while the proportion from East Asia has declined by $7 \%$ (CBIE, n.d.). There are a number of noteworthy changes in terms of the top countries where international students migrate to Canada. Recently, the United Kingdom has no longer been one of the leading migration sources of international students to Canada. Instead, South Asia, particularly India and Vietnam, have been leading sources of international students in Canada (CBIE, n.d.).

While international students in Canada continue to increase at an alarming rate, domestic students' enrollment has been declining across the country, triggering tuition revenue loss for most Canadian educational institutions. At a time that Canadian universities have been struggling to maintain sufficient enrollment of domestic students, international students' admissions have compensated for any financial and economic losses universities may have incurred from the decline of domestic students' enrollment. Our analysis is much more nuanced, taking into account significant differences of international students across the Canadian provinces. From a regional perspective, Ontario is the 
primary beneficiary of international students' economic contribution. In 2019, IRCC reported that Ontario hosted some $48 \%$ of Canada's international student population - nearly 307,000 people. British Columbia was a distant second, with $23 \%$ of Canada's international students - about 145,000 people. Quebec was third, with $14 \%$ of all international students in Canada - 87,000 people (IRCC, 2019). Thus, any decline in international students' enrollment potentially hurts these provinces. Consequently, the economic impact of the COVID-19 pandemic on educational institutions in Ontario, Quebec, and British Columbia could be gravely severe. These popular Canadian study destinations for international students will experience a drastic decline in international students' recruitment and retention.

Apart from the tuition revenue, international students in Canada are critical for stabilizing the aging Canadian population growth. According to Statistics Canada (2018), the Canadian population is aging rapidly, while fertility and birth rates are precipitously declining. The Conference Board of Canada (2019) warned that the aging Canadian population has created a gap in the Canadian labor force. As the country's natural birth rate continues to decline, immigration from foreign nationals, including international students, is compensating for the decline in the natural birth ratio (Statistics Canada, 2018) to stabilize the Canadian labor force. While the Conference Board of Canada (2019) predicted that population growth driven by immigration (including international students) could put the GDP annual growth rate at $1.8 \%$ from 2018 to 2040 , this estimated growth is being interrupted by the COVID-19 pandemic.

\section{Analyzing the Impact of the COVID-19 Pandemic on International Students and International Education in Canada}

The burgeoning research on COVID-19 has confirmed that the virus was initially detected in November 2019 at Wuhan in China and swiftly spread to all countries and territories in the world. At the time of completing this article, almost 120 million COVID-19 cases, with more than 2.7 million deaths, have been reported worldwide (World Health Organization [WHO], 2021; Worldometer, n.d.). Canadian health authorities have also reported almost just shy of $1,897,000$ cases and over 30,000 deaths from COVID-19 (Health Canada, 2021). This data is astounding. While people with weakened immune systems from underlying medical conditions are deemed the most vulnerable to the pandemic, older adults above 60 years, Indigenous people, and low-income Canadian families are also deemed vulnerable (Health Canada, 2021). One group of people conspicuously missing from the vulnerable groups' list is international students who, by their immigration status, are severely impacted by the virus socially and economically (Firang, 2020). Health experts have stated that there is little or no pre-existing immunity against coronavirus, and the virus does not discriminate against people (WHO, 2020), including international students. Thus, the COVID-19 global pandemic can impact every facet of international students, who are profoundly compressed by the uncertainty surrounding their higher education. 
To mitigate the spread of the virus, the response to the COVID-19 crisis has been focused on medical intervention, containment, and vaccination (WHO, 2020, 2021). Governments worldwide, including Canadian governments, have moved in unison to pass emergency legislation that prioritizes and enforces safety measures, such as social distancing and lockdown conditions and border closures - to stop the spread of the virus. Following governments' leads, Canadian universities have also shut down their campuses (Firang, 2020). To alleviate the pandemic's social and economic costs, Canada has shown compassion to the most vulnerable people, including the elderly and low-income families, by providing emergency financial relief and social programs for most Canadians (Firang, 2020). These financial and social safety programs, especially the Canadian Emergency Student Benefit (CESB), Canada Emergency Response Fund (CERB), and Employment Insurance (EI), provide most Canadians with a sense of economic security and a social safety net. Unfortunately, international students, considered nonpermanent residents, have not been eligible for the CESB. Also, most international students are exempted from EI because most of them only work part time and do not meet the required working hours for EI benefits. Only those international students working part time throughout the school year have been eligible for the CERB. Thus, most international students have been exempted from government relief programs aimed at mitigating the social and economic costs of the pandemic. Meanwhile, international students, who make high contributions to the Canadian GDP by paying astronomically high tuition fees, have limited job opportunities in Canada. Thus, for international students in Canada, the economic effects, especially the financial impact, of COVID-19 has been exacerbated. Statistics Canada (2020) estimated that international students in Canada, on the average, spend between $\$ 30,000$ and $\$ 50,000$ to attend a Canadian post-secondary institution. Most international students in Canada carry an enormous financial debt burden because they borrow from their homeland's financial institutions where interest rates are typically higher. Many international students engage in part-time jobs to offset their financial burdens while studying in Canada. Upon graduation, most of them apply for Canada's postgraduation work permit in the hopes of saving enough money to minimize their financial debt, as well as building enough Canadian work experience to allow them to apply for permanent residency status in Canada (Monteiro, 2020). Unfortunately, for international students, the COVID-19 pandemic has triggered an abrupt and ongoing harmful impact on the Canadian economy. With rising unemployment amid the pandemic, most international students in Canada will unlikely find jobs to meet their financial needs. Given that the number of cases and fatalities from the pandemic continues to rise, international students will continue to face unemployment for several months, if not years, until the Canadian economy recovers from this pandemic. Undoubtedly, the financial burden from the COVID-19 pandemic can be daunting for international students' well-being. 


\section{Psychosocial Impact on International Students}

Besides the financial difficulties the pandemic brings upon international students in Canada, this group of students, who already face a relative disadvantage due to language barriers, fewer family and friend networks, and precarity of their legal immigration status, are at risk of psychosocial problems, including anxieties, depression, and mental health problems from self-isolation measures. Thus, measures like travel constraints, lockdown restrictions, and campus shutdowns, aimed at controlling the spread of the virus, are more likely to throw international students in Canada into a severe state of anxiety. International students will experience more difficulties adjusting to and managing the current pandemic crisis in the absence of financial and social supports. What is more disturbing is that before the COVID-19 outbreak, international students in Canada already experienced social exclusions, overt racist aggression, and cultural barriers (Belkhodja, 2013; Zhang \& Zhou, 2010), although Canadian schools and universities promote multiculturalism on their campuses. Hence, policy measures that exclude international students from financial and social relief programs, coupled with government restrictions and other punitive measures aimed at containing the spread of the virus, not only create more financial problems but also create psychological distress for international students, making them more vulnerable to the pandemic than many people in Canada. As international students grasp for answers in the dark era of COVID-19 predicaments, they will look to their universities for guidance and support. How universities create and organize supports to aid international students during the current crisis can set the tone to alleviate international students' anxieties and stresses to maintain steady enrollment of international students. Failure to support international students through the pandemic will likely lead to decline in international student enrollment in Canadian universities.

\section{Impact on International Educations and Canadian Economy}

The current COVID-19 pandemic is not only affecting international students, but also gravely impacting Canadian universities' capacities to recruit and retain international students, triggering a significant drop in international student enrollment. A decrease in international students' intake will have serious financial consequences for Canadian universities. Hagar (2020) found that a decline in international student enrollment has been fueled by the disruption of internationalization programs, such as student recruitment and study abroad programs. Border closures and travel restrictions have disrupted recruitment season and study abroad programs (Hagar, 2020). At the time of completing this article, Canada has seemingly relaxed border restrictions for international students from the United States; however, even if the Canadian government relaxes its immigration policies for international students, most students cannot travel to Canada due to international border closures (IRCC, 2020). Thus, a decline in international student enrollment poses significant tuition revenue shortfall for Canadian educational institutions. 
Canadian universities are not evenly impacted by COVID-19. As stated earlier, universities in Ontario, British Columbia, and Quebec are the primary beneficiaries of international student populations and will be more impacted than other universities in the maritime provinces. Consequently, the economic impact of the COVID-19 pandemic on educational institutions in Ontario, Quebec, and British Columbia may be gravely severe. These popular Canadian study destinations for international students will experience a drastic decline in international students' recruitment and retention, hence significant revenue shortfalls.

A significant decline in international student enrollment will also hurt the Canadian economy, given that international students contribute to more than $\$ 21.5$ billion to the Canadian economy (Table 1). As noted earlier, the Conference Board of Canada (2019) prediction of Canada's GDP annual growth rate at 1.8\% will be interrupted by the COVID-19 pandemic due to the shortfall of international student enrollment. A drop in international students could also affect the number of new permanent residents in Canada. A significant reduction in Canada's international students could also hurt municipalities, small businesses, and landlords in these provinces who depend on these students for revenue.

\section{Issues of Human Rights}

The Canadian government's declaration of a state of emergency and lockdown measures to "flatten the curve" (i.e., minimize the spread of the virus) with minimal support for international students has human rights implications. When the novel coronavirus was declared a pandemic, governments worldwide declared a state of emergency and initiated punitive regulations, such as physical distancing and lockdowns to contain the virus. Except for those people engaged in essential services, all Canadians, including international students, were forced to stay at home. Penalties for breaching the COVID-19 lockdown protocols were massive, with on-the-spot fines of $\$ 1,500$. The lockdowns were decreed with short notice. Most international students hurriedly had to leave their university campuses. Panic-stricken international students made efforts to go home to their parents, but many could not do so because of international travel restrictions and border closures.

The United Nations High Commissioner for Human Rights warned that defying the rule of law to combat the COVID-19 pandemic risks sparking a human rights violation (Human Rights Watch [HRW], 2020). One can argue that the lockdown restrictions limit the democratic right of freedom of movement for international students. Under the Canadian Charter of Rights and Freedom and international human rights law, every human being, including international students, has the right to freedom of movement, including the right to travel within and across national boundaries (Canadian Human Rights Commission [CHRC], n.d.). We contend that travel restrictions and border closures are imposed for a legitimate purpose, especially during the current pandemic. However, some international human rights activists have questioned the legitimacy of restricting human mobility and freedom of movement during the lockdown (HRW, 2020). 
These concerns seem legitimate for international students, who have no families in Canada, but have had to leave their university campuses unexpectedly, although they could not go home to their families because of international travel restrictions.

Furthermore, government measures to curb the pandemic have raised concerns about socioeconomic rights violations for international students. For instance, excluding international students from most relief programs and support during the pandemic is unjustifiable, and has raised concerns about socioeconomic rights violations against international students, especially given the contributions international students make to the Canadian economy (Firang, 2020). International human rights activists and United Nations High Commissioner for Refugees (UNHCR) have cautioned that emergency measures to contain the virus should not go against particular groups or individuals, particularly refugees and international students, who hold irregular immigration legal status (HRW, 2020; United Nations High Commission for Refugees [UNHCR], 2020). Canada's exclusion of international students and other temporary residents from financial and social relief programs not only seems harshly ill-conceived and insensitive but also can be deemed as violating the socioeconomic rights of international students (Firang, 2020).

\section{ADDRESSING THE IMPACT OF THE PANDEMIC}

Our analysis of the strategies required to tackle the pandemic's impact on international education in Canada is addressed at two levels: micro and macro. At the micro-level, we approach our analysis with direct application of our psychological model of resiliency in framing the experiences and capacities of international students to develop healthy coping mechanisms to adapt to the challenges the pandemic presents. In this context, we believe that empowering international students to build resilience can provide them with the strength to cope with the pandemic. We contend that universities can draw on their internal resources, such as professional support groups from their health science, psychology, and social work departments, to assist international students in dealing with the pandemic consequences. For instance, upper-year social work, psychology, and nursing students in the various Canadian universities can act as support working groups to voluntarily offer services in mitigating the pandemic effects on international students. These to-be practitioners in various Canadian universities can conduct psychosocial assessments to identify and understand international students' capacities and strengths to empower international students to cope with the pandemic. Understanding international students' resilience amid the COVID-19 pandemic requires an analysis of how international students draw on motivational aspirations and social resources to allow them to access community supports to deal with the crisis (Akbar \& Preston, 2019; Lester \& Nguyen, 2015). We believe these resilience (strength-based) interventions can also empower international students to move beyond vulnerability amid the COVID-19 pandemic to discover their vitality and agency — moving from the idea of victimhood to resilience to deal the pandemic themselves. 


\section{Macro-Level}

While the micro-level strategies allow universities to directly engage with international students, it is at the macro-level that universities can develop policies and strategies to address the issues that impact international students' well-being amid the current global health crisis. Our analysis at the macro level takes into consideration the significant differences between capacities of universities across Canada to better support international students. Universities and colleges across Canada are not resourced nor funded evenly. Financial resources and staffing discrepancies between smaller and bigger schools across the various provinces in Canada impact the quality and quantity of international student support (Hagar, 2020). The discrepancies in the level of support from Canadian universities for international students are due to postsecondary education in Canada being within the jurisdiction of the provinces. Apart from tuition revenue, Canadian universities receive most of their funding from provincial government sources (Statistics Canada, 2018). The remaining funding comes from donations, private grants, investments, and other minor sources of revenues. Universities in Ontario, Alberta, and British Columbia are more likely to receive better funding for international students than universities in the maritime provinces whose governments are financially handicapped. An exception can be made for Newfoundland, which has only one university and benefits from huge provincial financial support for international students. Some universities, such as the University of Toronto and McMaster University in Ontario operate with a large budget from an inflow of alumni and capital investments. Thus, we wish to remind our readers that some universities are less capable to offer support for international students.

Ensuring international students' safety and security amid the COVID-19 pandemic is a necessary strategy universities need to establish to protect the lives of international students. Strategies to protect the lives of international students should not be different from policies aimed at protecting all other students and employees. However, international students will require special care due to their vulnerabilities and precarity around their legal status in Canada. These protective strategies include all public health measures aimed at mitigating the spread of the virus, including physical distancing protocols, masking policy, and contact tracing (Health Canada, 2021). In addition to the policies to secure international students from the pandemic, Canadian universities should adopt flexibility to meet international students' academic needs. Canadian universities should accommodate international students' learning needs by revising academic services and operations to accommodate virtual and remote learning designed to support international students. Remote learning, which is changing the future of education, gives international students more learning options. However, for some international students, online learning may be challenging, especially in professional and technical programs that require field practice.

Canada's universities can partner with the Canadian governments in combatting the COVID-19 pandemic in many ways. Besides offering a vaccine for students, Canadian universities can work with the federal and provincial 
governments to address the pandemic's impacts on international students. Assessing the systemic and institutional issues that impact international students' well-being is important. For instance, Canadian universities need to identify underlying immigration policies that treat international students as the "others" and deny them of public support. Universities should also play the role of activists, on behalf of international students, to advocate for public support and social programs, while seeking to change institutional arrangements in the Canadian society that deny compassion to international students during this pandemic. At the very least, concerted efforts from both the universities and government are required in speeding up study permit applications for international students during this pandemic period. Canadian educational institutions should also raise awareness about the plight of international students amid the pandemic and persuade the government to pursue social justice for all people, regardless of their immigration status (Firang, 2020).

\section{CONCLUSION}

Drawing on various literature sources, including secondary data and media reports, we have demonstrated that international students who seek higher education in Canada make an enormous contribution to the Canadian economy. The current global health crisis brought about by COVID-19 is woefully impacting international students, who are very vulnerable to the pandemic, but nonetheless are excluded from most government financial support programs aimed at alleviating the pandemic's social and economic impact. Excluding international students from relief programs and supports during the pandemic is unjustifiable and raises concerns about international students' socioeconomic rights violations. Due to their temporary legal immigration status, most international students in Canada, who already experience psychological and financial challenges, now experience more difficulties adjusting to, and managing, the current pandemic crisis. The COVID-19 pandemic not only creates challenges for international students, but also creates economic difficulties for Canadian universities, as a reduction in international student enrollment creates significant tuition revenue shortfall.

Amid the current pandemic, conventional theoretical frameworks of the neoclassical economic perspective, push-pull model, and neo-liberalism cannot adequately explain international students' mobility. Psychological theoretical perspectives, especially crisis and resilience models, are better frameworks to address international students' mobility, recruitment, and retention in the era of the global health crisis. In light of this, there are key strategies as to how international students and Canadian educational institutions can respond to the COVID-19 pandemic. Thus, this article offers strategic direction for universities worldwide to respond to the pandemic crisis.

We caution our readers about the COVID-19 data in this study, as there are many unknowns about the pandemic. However, the article offers some bases for further research and action. At the least, the article lays a foundation for more extensive research studies to examine the social and economic impact of 
COVID-19 on international education. Studies that generate evidence-based knowledge and responses to address the social and economic implications of the COVID-19 crisis on international students' enrollment in Canadian universities are necessary. Also, an empirical study that elicits detailed information about international students' experiences during the COVID-19 outbreak is important. Furthermore, research studies that analyze international student enrollment amid the COVID-19 pandemic will reveal the real economic impact of the pandemic on the Canadian educational sector.

\section{REFERENCES}

Akbar, M., \& Preston, V. (2019). Migration and resilience: Exploring the stock of knowledge review of literature: 2000-2016 [Research report]. York University, CERIS. https://bmrc-irmu.info.yorku.ca/files/2020/06/Imm igrants-and-Resilience-Working-Paper_Final_new7.pdf?x15611

Belkhodja, C. (2013). Improving the assessment of international students' contribution to Canadian society. http://p2pcanada.ca/wp-content/uploads/ 2014/02/International-Students-Contribution-to-Canadian-Society.pdf

Boyd, M. (2013). Recruiting high skill labour in North America: Policies, outcomes and futures. International Migration, 52(3), 40-54. https://doi.org/ 10.1111/imig. 12139

Canada Bureau for International Education. (n.d.). International students in Canada. Retrieved March 26, 2021, from https://cbie.ca/infographic/

Canadian Human Rights Commission. (n.d.). Human rights in Canada. Retrieved December 21, 2021, from https://www.chrc-ccdp.gc.ca/en/about-humanrights/human-rights-canada

Choudaha, R. (2017). Three waves of international student mobility (1999-2020). Studies in Higher Education, 42(5), 825-832. https://doi.org/10.1s080/ 03075079.2017.129387

Conference Board of Canada. (2019). Can't go it alone: Immigration is key to Canada's growth strategy. https://www.conferenceboard.ca/e-library/abstract. aspx?did=10150\&AspxAutoDetectCookieSupport $=1$

Dorado Barbé, A., Pérez Viejo, J. M., del Mar Rodríguez-Brioso, M., \& GallardoPeralta, L. P. (2021). Emotional well-being and resilience during the COVID19 pandemic: Guidelines for social work practice. International Social Work, 64(2), 279-284. https://doi.org/10.1177/0020872820970622

Fakhar-e-Alam, M., Bhutta, Z. A., Shabbir, S., \& Akhtar, M. (2020). Psychosocial impact of COVID-19 outbreak on international students living in Hubei province, China. Travel Medicine and Infectious Disease, 37, 101712. https://doi.org/10.1016/j.tmaid.2020.101712

Ferdiansyah, S., Supiastutik, \& Angin, R. (2020). Thai students' experiences of online learning at Indonesian universities in the time of the COVID-19 pandemic. Journal of International Students, 10(S3), 58-74. https:// doi.org/10.32674/jis.v10iS3.3199 
Firang, D. (2020). The impact of COVID-19 pandemic on international students in Canada. International Social Work, 63(6), 820-824. https://doi.org/ $10.1177 / 0020872820940030$

Global Affairs Canada. (2017). Economic impact of international education in Canada-2017 update. https://www.international.gc.ca/education/reportrapport/impact-2017/index.aspx?lang=eng

Hagar, H. (2020). The economic impact of international students in Northern Ontario. Northern Policy Institute.

Health Canada. (2021, December 20). Coronavirus disease (COVID-19): Outbreak update. Government of Canada. https://www.canada.ca/en/ public-health/services/diseases/2019-novel-coronavirus-infection.html?topic= tilelink

Human Rights Watch. (2020). Human rights dimensions of COVID-19 response. https://www.hrw.org/sites/default/files/supporting_resources/202003covid_ report_0.pdf

Immigration Refugees and Citizenship Canada. (2019). How COVID-19 is affecting business. https://www.canada.ca/en/immigration-refugees-citizenship/ services/coronavirus-special-measures.html

Immigration Refugees and Citizenship Canada. (2020). Study permit: About the process. https://www.canada.ca/en/immigration-refugees-citizenship/services/ study-canada/study-permit.html

International Education Canada. (2019). Building on success: Canada's international education strategy (2019-2024). https://www.international. gc.ca/education/strategy-summary-sommaire-strategie.aspx?lang=eng

James, R. K. (2008). Crisis intervention strategies. Brooks/Cole.

Kaplan, H. B. (2005). Understanding the concept of resilience. In S. Goldstein \& R. Brooks (Eds.), Handbook of resilience in children (pp. 39-47). Kluwer Academic/Plenum. https://doi.org/10.1007/b107978

King, R., \& Raghuram, P. (2013). International student migration: Mapping the field and new research agendas. Population, Space and Place, 19(2), 127-137. https://doi.org/10.1002/psp.1746

Lester, T. W., \& Nguyen, M. T. (2015). The economic integration of immigrants and regional resilience. Journal of Urban Affairs, 38(1), 42-60. https://doi.org/10.1111/juaf.12205

Lipura, S. J. (2021). Adding an international student's voice to the pandemic discourse as thinkers not subjects: Reflections on power, stillness and humanness. Journal of International Students, 11(1), 251-256. https://doi.org/10.32674/jis.v11i1.2564

Luthar, S. S. (Ed.). (2003). Resilience and vulnerability: Adaptation in the context of childhood adversities. Cambridge University Press.

Massey, D. S., Arango, J., Hugo, G., Kouaouci, A., Pellegrino, A., \& Taylor, J. E. (1994). An evaluation of international migration theory: The North American case. Population and Development Review, 20(4), 699-751. https://doi.org/10.2307/2137660 
McGill, J. (2013). International student migration: Outcomes and implications. Journal of International Students, 3(2), 167-181. https://doi.org/10.32674/ jis.v3i2.509

Menz, G. (2011). Neo-liberalism, privatization, and the outsourcing of migration management: A five-country comparison. Competition \& Change, 15(2), 116-135. https://doi.org/10.1179/102452911X13025292603633

Miller, G. (2011). Fundamentals of crisis counseling. Wiley.

Monteiro, S. (2020, May 15). International students are vital to Canada's economic recovery after COVID-19. Open Democracy. https:// www.opendemocracy.net/en/pandemic-border/international-students-are-vitalto-canadas-economic-recovery-after-covid-19/

Mullaly, B. (2010). Challenging oppression and confronting privilege. Oxford University Press.

Pappa, S., Yada, T., \& Perälä-Littunen, S. (2020). International master's degree students' well-being at a Finnish university during COVID-19. Open Education Studies, 2(1), 240-251. https://doi.org/10.1515/edu-2020-0128

Regehr, C. (2011). Crisis theory and social work treatment. In F. J. Turner (Ed.), Social work treatment: Interlocking theoretical approaches (pp. 134-143). Oxford University Press.

Robinson, R. (2005). Beyond the state-bounded immigrant incorporation regime. Transnational migrant communities: Their potential contribution to Canada's leadership role and influence in a globalized world. http://www.nsiins.ca/wp-content/uploads/2013/10/Transnational-Migrant-CommunitiesTheir-Potential-Contribution-to-Canadas-Leadership-Role-and-Influence-ina-Globalized-World.pdf

Sassen, S. (1988). The mobility of labor and capital: A study in international investment and labor flow. Cambridge University Press. https://doi.org/ 10.1017/CBO9780511598296

Statistics Canada. (2018). Population growth: Migratory increase overtakes natural increase. https://www150.statcan.gc.ca/n1/pub/11-630-x/11-630x2014001-eng.htm

Statistics Canada. (2020). International undergraduate tuition fees by field of study. https://doi.org/10.25318/3710000501-eng

United Nations High Commission for Refugees. (2020, March 16). Key legal considerations on access to territory for persons in need of international protection in the context of the COVID-19 response. https:// www. refworld.org/docid/5e7132834.html

Varghese, N. V. (2008). Globalization of higher education and cross-border student mobility, International Institute for Educational Planning, United Nations Educational, Scientific, and Cultural Organization. https://unesdoc.unesco.org/ark:/48223/pf0000157989/PDF/157989eng.pdf.m ulti

World Health Organization. (2020). Coronavirus disease (COVID-2019) situation report-175. https://www.who.int/docs/default-source/coronaviruse/ situation-reports/20200713-covid-19-sitrep-175.pdf?sfvrsn=d6acef25_2 
World Health Organization. (2021). Coronavirus disease (COVID-19) situation report-16 March 2021. Retrieved March 20, 2021, from https://www.who.int/publications/m/item/weekly-epidemiological-update--16-march-2021

Worldometer. (n.d.). Coronavirus updates. Retrieved March 20, 2021, from https://www.worldometers.info/coronavirus/

Zhang, Z., \& Zhou, G. (2010). Understanding Chinese international students at a Canadian University: Perspectives, expectations, and experiences. Comparative and International Education, 39(3), 43-58. https://doi.org/ 10.5206/cie-eci.v39i3.9162

DAVID FIRANG, PhD, is an assistant professor at the Department of Social Work, Trent University. His scholarly interests are in international migration and transnationalism, immigrants' housing, and social policy. Email: davidfirang@trentu.ca

JOSEPH MENSAH, PhD, is a professor and a former chair of the Department of Geography at York University, and a former associate director of the Harriet Tubman Institute for Research on the Global Migration of African Peoples at York University. His research focuses on globalization and culture; immigrant housing and transnationalism; race, gender, and employment; and African development. Professor Mensah has received several competitive awards and grants from the Social Sciences and Humanities Research Council of Canada (SSHRC), Canada Housing and Mortgage Corporation, the Gates Foundation, the Commonwealth Secretariat in London, and the International Labour Organization (ILO). Email: jmensah@yorku.ca 